\title{
Abuse and Violence Against Foreign Domestic Workers. A Case from Hong Kong
}

\begin{abstract}
This paper explores various abuses Foreign Domestic Helpers (FDHs) or migrant domestic workers (MDW) in Hong Kong suffer and the strategies they take up to cope with this abuse. Data were collected from 215 domestic helpers (135 from the Philippines, 30 from Thailand, 41 from Indonesia, and 9 from Sri Lanka) all of whom had been in residence for at least six months. Selected by snow-balling technique, respondents were interviewed with structured and non-structured questionnaires. Research shows that sexual abuse is the most common form of abuse against MDWs followed by psychological and physical abuses. Female employers are the main perpetuators of psychological abuse while the male employers are culpable for sexual abuses. Coping strategies varied widely among the MDWs. Many of them endure the violence to keep the job; some quit the job and others struggle with the decision to stay or quit.
\end{abstract}

Key words: Abuse, violence, Domestic helper, Hong Kong

\section{Introduction}

What are the sources of vulnerabilities of migrant populations, especially the migrant domestic workers and how varied are the forms of their vulnerabilities? Unskilled and low skilled migrant populations and the susceptibility to 'abuse' have not received adequate research attention. The sensitivity and invisibility of the issue, difficulty in measuring and disclosing are primary reasons why this issue remained under-researched. The lack of protection from host States, gender disparity and neglect of human rights lead employers to systemically abuse this vulnerable section of population. We often say that a qualitative change in migration has taken place in the last decade meaning that women migrate more in number independently than before. In some countries in Asia, female migrants have outnumbered their male counterparts. This notion has increasingly been known as 'feminization of migration' which has been most marked in the Philippines, Indonesia, Thailand and, Sri Lanka. A 
significant percentage of female migrants is constituted by foreign/migrant domestic workers (henceforth MDWs) whom I call 'replacement migrants'. The demand for MDWs in countries like Japan, Korea, Hong Kong, Macau', Singapore, and Malaysia is very high. With the aging population growing and increasingly female workforces participating in job market, the need for domestic workers began to rise meaning that MDWs are taking up the role of household chores. MDWs constitute approximately five per cent of the population of Hong Kong and about 98 per cent is female (Ullah, 2013; Lin and Nana, 1996).

From early 1970s and late 1980s, the migration flow in general and female migration in particular had been predominantly to the 'newly' oil rich countries in the Middle East. A partial 'direction shift' of Asian [female] migrants' to some Southeast and East Asian countries began due largely to the booming economies. By 1997, destinations such as Malaysia, Taiwan, Singapore, Japan, Hong Kong, Macau and South Korea came to the fore (Abella, 2003; Ullah 2010; 2014). This redirection from the oil rich countries has been marked due partly to the reported violence against them, abuses and declining salary base (IOM, 2005, Ullah, 2013a; Ullah, Hossain and Islam, 2014b). Abuse is often associated with the kind of jobs the migrant workers are in such as the three ' $\mathrm{D}$ ' (dirty, difficult, and dangerous) jobs (Machado, 2003). This does not necessarily mean that abuses do not happen elsewhere. In fact, every year, consulates and embassies of sending countries to Hong Kong receive thousands of complaints from domestic workers about non-payment of wages, excessively long working hours without rest, and physical, sexual, and psychological abuse. Many more abuses likely remain unreported. Of course, this is not the case for the skilled workers. Gender of the workers, exposure, origin, level of skill and education often determine the level and types of abuse. Abuse continues when perpetrators are given impunity.

Migrant domestic workers ${ }^{2}$ have become very much a part of Hong Kong middle class life style (Ullah, 2013). They have increased in number phenomenally since the last three decades. Since the 1970 s the population of the non-Chinese migrant workers has steadily grown. In the mid 1970s, Hong Kong allowed a limited number of MDWs from the Philippines to enter the territory for work. As the economy expanded, so did the demand for MDWs. In 1982, there were 20,959 MDWs legally registered, and 96 per cent were from the Philippines. By 1990, this number increased to 141,368 and included mainly Filipinos, Thais, and Indonesians. By May 2000, the numbers of MDWs reached 202,900 or 41 per cent of the foreign population in Hong Kong (Loper, 2001). There were about 320,000 MDWs in 2013. However, some changes have taken place. For example, currently 50 per cent comes from the Philippines, 47 per cent from Indonesia, and the rest from Thailand, Myanmar, Bangladesh, Nepal, Pakistan and Sri 
Lanka (Hong Kong Immigration, 2013). Recently, Bangladesh has entered into this market, meaning that more sending countries are entering in the Hong Kong MDW market.

There are more than 53 million domestic workers in the world and most of them are women. The true figure would be more than 100 million. About 41 per cent of them are working in the Asia Pacific region (ILO, 2013). Hong Kong opened its doors to these maids and caretakers in the mid-1970s. Today Hong Kong recruits one of the highest number of domestic workers in the world. One in every eight households, and one in every three households with children, employs a housekeeper, usually a foreigner. They make up about 10 per cent of the working population, and 5 per cent of the overall population (Ullah, 2013). Generally, Filipino workers replaced Chinese domestic workers in the 1980s as the mainland economy took off. In Hong Kong female employment has grown to $54.7 \%$ as of 2013 , from $47.5 \%$ in 1982 . This means that Hong Kong needs these domestic helpers as much as the workers themselves need the work. Domestic workers have become synonymous to the word 'Filipina'. Employers often refer to their housekeeper generically as "my Filipina". Sadly, they do dirty jobs and they are often treated as dirty object. Increasingly draconian policies in Hong Kong are exposing more migrant domestic workers to abuses. They are not treated as workers, they are treated as helpers (ILO, 2013).

Table 1. Respondents and their age distribution

\begin{tabular}{|c|c|c|}
\hline Countries of origin & $\mathbf{f}$ & $\mathbf{\%}$ \\
\hline Philippines & 135 & 62.8 \\
\hline Indonesia & 41 & 19.1 \\
\hline Thailand & 30 & 13.95 \\
\hline Sri Lanka & 9 & 4.2 \\
\hline Total & 215 & 100.05 \\
\hline Age group & $\mathbf{f}$ & $\mathbf{2 1 . 8 6}$ \\
\hline $\mathbf{2 0 - 2 5}$ & 47 & 20.93 \\
\hline $\mathbf{2 6 - 3 0}$ & 45 & 18.61 \\
\hline $\mathbf{3 1 - 3 5}$ & 40 & 17.67 \\
\hline $\mathbf{3 6 - 4 0}$ & 38 & 13.95 \\
\hline $\mathbf{4 1 - 4 5}$ & 30 & 6.98 \\
\hline $\mathbf{4 6 - 5 0}$ & 15 & 100 \\
\hline Total & 215 & \\
\hline
\end{tabular}

Source: Field data 
This paper argues that while Hong Kong boasts better protection mechanisms it has in place, individual mindset towards treating domestic helpers determines how they are treated. This means that domestic policy or international rights mechanism may have little to do with upholding human rights of the MDWs. Does 'abuse' know boundaries or law? More or less, it prevails everywhere at different levels and in scales. Some countries have good laws to protect the right of MDWs while some countries lack enforcement, some country's legislation precludes issues of MDWs by not recognizing them as labourer. ${ }^{3}$

Abusive treatment of MDWs is a common complaint against employers and recruiting agents. Visibility of an abuse depends on the kind of abuse, for example, verbal abuse or physical abuse in private part of the body. Therefore, most incidents of abuses remain un or under-reported. While Hong Kong is one of the safest destinations for the MDWs, surprisingly reports of abuses are still very common. Abuse may stem from racial discrimination in the workplace. Is Hong Kong a racist country? Many scholars argue that abusive policies and poor working conditions are manifestations of racism with regard to ethnic background (Lin, 2004; Parrenas, 2001; Simons, 1999; Sobsey, 1994; Ullah and Huque, 2014b).

This research explores the extent of different forms of abuses (sexual, psychological and physical) perpetrated on the MDWs in Hong Kong. Coping strategies used by MDWs have rarely been examined. Seldom do studies account for the cumulative abuse women have experienced over their life course, and little is known about how women take actions over time. This study further explores how the victims try to cope with the abusive situations they encounter. Both closed and open-ended questionnaires were administered. Data was collected from Sham Shui Po, Kowloon Tong, Tsim Sha Tsui, Aberdeen, Mongkok, Causeway Bay, Kennedy Town and Central Star Ferry areas in Hong Kong. A total of 215 MDWs (135 from the Philippines; 41 from Indonesia; 30 from Thailand; and 9 from Sri Lanka) were selected on snow-ball basis for interview (Table 2). This research went through ethical review board because this deals research involved human subjects. Their written and verbal consent were obtained before the interview began. The identity/names were never been disclosed. The reference period of the abusive experience is one and half year from the time of interview.

An overwhelming majority of the respondents were single. Irrespective of their marital status, they moved unaccompanied. About 7 per cent reported to have their children back at home. Their un-accompaniment and marital status have implication for their level of abuse. 
Table 2. Marital status

\begin{tabular}{|c|c|c|}
\hline Marital status & $\mathbf{f}$ & \% \\
\hline Married & 21 & 9.78 \\
\hline Single & 136 & 63.25 \\
\hline Separated & 43 & 20 \\
\hline Divorced & 15 & 6.97 \\
\hline Total & 215 & 100 \\
\hline Current status & $\mathbf{f}$ & $\%$ \\
\hline Have kids at origin & 16 & 7.44 \\
\hline Have boyfriend at origin & 37 & 17.20 \\
\hline Have boyfriend at destination & 41 & 19.1 \\
\hline Married (as mentioned) & 21 & 9.76 \\
\hline NR* & 100 & 46.50 \\
\hline Total & 215 & 100 \\
\hline
\end{tabular}

Source: Field data

No response

Respondents: The highest percentage of respondents came from the age group of 20-25. This number perhaps resembles with the tenet of the theory that contends that younger people want to embark upon challenges and set off for opportunities overseas, while the elderly prefer to stay home and take care of the remained behind (Ullah, 2010). One of the implications of the respondents' age is that they might be more susceptible to sexual abuse if not protected (Simons, 1999) meaning that there is a negative correlation between their susceptibility to sexual abuse and their level of protection/ power to be protected.

Table 3. Length of stay in Hong Kong

\begin{tabular}{|c|c|c|}
\hline Years & f & \% \\
\hline$<2$ & 54 & 25.5 \\
\hline $2-5$ & 114 & 53 \\
\hline $6-8$ & 33 & 15 \\
\hline $9-11$ & 14 & 6.5 \\
\hline
\end{tabular}

Source: Field data

About 10 per cent of the respondents were married, while twenty per cent were separated, seven per cent were divorced, and the majority of them (63 per cent) were single (see Table 2). In terms of the education level of respondents, a majority of the respondents had a Bachelor or Master level of education. Many of them reported to have nursing degrees. 
Duration of residence in Hong Kong was one of the variables to select the respondents. Those who had been living in Hong Kong less than six months were deliberately excluded from the study. A majority of the respondents had been working in Hong Kong for between two and five years. Only fifteen per cent had been there between six and eight years and seven per cent had remained in the country for between nine and eleven years.

\section{Framing violence and abuse}

Violence and abuse are broad terms in terms of the type of conduct and type of relationships that fall within the definitions of violence and abuse. This paper considers violence and abuses in the framework of analysis based on the experiences of the MDWs and literatures available. Violence is gendered meaning that there is a gender division between perpetrator and perpetrated (Price, 2005). This does not preclude the perception that women could commit violence. However, power relation determines who are the perpetrators. Marshall (1999) argues that three different scales of violence are detrimental to women: overt, obvious and subtle. Marshall further goes on to say that violent acts include verbal aggression and controlling behaviours, whereas overt acts include dominating and discrediting behaviours, and subtle acts include isolating and undermining behaviours. Researchers have tried to link Marshall's theory with reality of the existence of five major categories of abuse i.e. sexual, psychological, emotional, economic and physical.

I am not using abuse and violence interchangeably because they are distinct from each other. However, abuse may lead to violence. With the understanding that abuse turns violence when it causes fear to one's life. Psychological abuse is a part of the continuum of abuses. This encompasses acts of confinement, isolation, verbal assault, humiliation, intimidation, infantilization, or any other treatment, which may diminish an individual's sense of identity and dignity (Straight et al., 2003) leading a person to feel being "less of a person" (Lemon et al., 2002; Clements et al, 2004). This has direct association with physical health problems. Smith and colleagues (2002) found that psychologically abused persons have more reproductive complications. And associated stress, related to psychological abuse, weakens the immune system (Straight et al., 2003; Lemon et al., 2002). Psychological abuse, when compared with physical violence, is strongly correlated with health symptoms (Coker et al., 2002 and Vitanza et al., 1995).

Sexual abuse involves touching, or inviting anyone to touch in a sexual way. According to the Canadian Department of Justice (2005), sexual abuse include: any kissing, fondling, touching, oral/anal sex or sexual intercourse without consent; not stopping sexual contact when asked to; forcing someone to engage in sexual intercourse or any other sexual act that may also include incest, 
sodomy, exhibitionism, or involving a child in prostitution or pornography. Additionally, Stalking which is another form of sexual abuse includes being followed or spied on, receiving threatening and/or unwanted phone calls, e-mails, letters and unwanted gifts (Department of Justice Canada 2005). Sexual abuse and sexual harassment are conceptually distinctive. Sexual harassment is any unwelcome behaviour, sexual in nature that adversely affects, or threatens to affect, directly or indirectly, a person's job security, working conditions or prospects for promotion or earnings; or prevents a person from getting a job, living accommodations or any kind of public service (Stone and Neale, 1984; Department of Justice Canada, 2005a, Alberta Human Rights and Citizenship Commission, 2004).

Physical abuse encompasses a range of abusive acts such as: slapping; choking; punching; hitting; kicking; pushing; shoving; pinching; biting; beating; spanking; scratching; grabbing; throwing bodily; burning; restraining and spitting. Forms of Physical violence includes beatings using methods such as shoes, belts, sticks; knocking heads against walls; and burning skin with irons, among other forms of violence. Employers or labor agents may inflict physical abuse so severe that it leads to a domestic worker's hospitalization or death. The perpetrators included: employers, older sons, daughters, wives and household heads (Straight et al., 2003; Doezema, 1998; Gamburd 2000). Putting MDWs in perspective, economic abuse is conceptualized by a few factors such as holding salary, paying salary delayed, threat to cut salaries, stop paying salaries, partial payment of salaries etc., among others.

Some scholars view this kind of violence through two concepts of critical theory. One is that any phenomenon in the society should be viewed from the entirety of society in its historical specificity and the other one is that improving the understanding of society by integrating all the major social sciences. However, social stratification may have implications in perpetration of violence and abuse towards the MDWs. Of course, social stratification refers to a system by which a society ranks categories of people in a hierarchy. Once people are placed on ranks, treatment towards them are allocated according to the ranks.

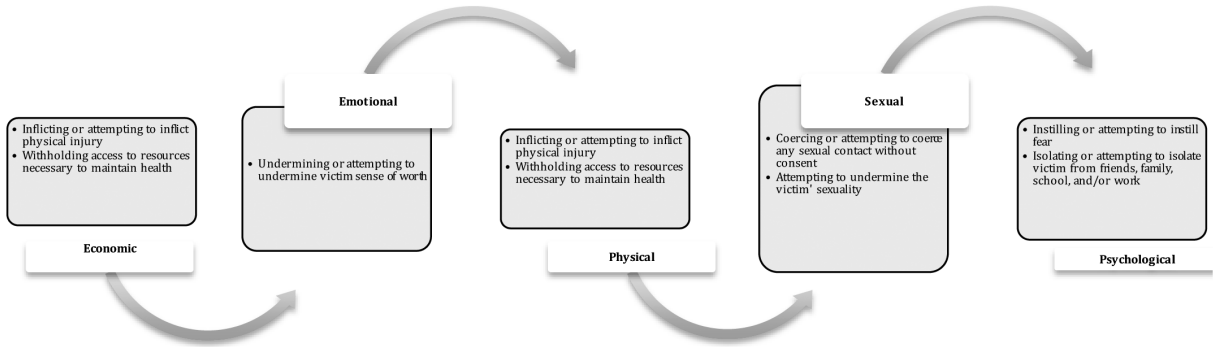

Figure 1. Adopted from Coker et al., 2003; Fry and Barker 2001; Smith et al., 2002; Straight et al., 2003 


\section{Hong Kong as a receiving point}

Long colonial history of Hong Kong and one of the major transit points of migrants from many Asian countries have made Hong Kong a multi-ethnic migrant community. Majority of the migrants are from mainland China (Wong et al., 2008:3). The introduction of migration control between the Mainland China and Hong Kong has resulted in the creation of a Hong Kong identity (Nagy, 2013; Ma, 2007). Migration policies have facilitated the migration of the highly skilled/professionals in finance and service sectors, and later migrant domestic workers to come into Hong Kong to work as maids/helpers has liberated Hong Kong women from the demands of balancing work and care-giving (Nagy, 2013). This means that MDWs have occupied significant space in the life of Hong Kong people. However, they are often vulnerable to abuses at various stages such as by public institutions, private recruitment brokers, or personal networks (Shuto, 2006). Both abuse and violence begin from the very first step of their recruitment process. There are complaints that recruiting agencies in varied ways abuse them ranging from economic to physical and emotional abuses. However, though after a record number of complaints against recruitment agencies for domestic helpers in 2013, the Labour Department denied license renewals to only four out of 1,250-odd during the period (World News, 2014) which implies that a culture of immunity is given to the abusive recruiting agencies. According to some researchers abusive treatment of MDWs is often determined by their class or economic status and race (Abraham, 2000). As such Loper (2001) argues that majority of MDWs were discriminated against because of their low professional position.

A few employers said that they already knew who to behave in what way. This means that a Sri Lankan is treated differently from a Filipino. MDWs as well estimate what kind of treatment they are going to be accorded. In case the employer is a 'foreigner' (referred usually to non-Chinese), they expect to be treated better than locals. When I asked one of the respondents who was from the Philippines about her experiences, she candidly said 'the day I arrived, madam and sir whispered each other. I realized it was about me. I did not speak their language, still they had to whisper pointing at me. I knew my strategies to cope with any situation. That was not my first job. I had way more difficult employer in Korea'. Clearly, this respondent was resilient. This however, does not mean that she did not experience abuse. She confessed that all forms of abuses were perpetrated on her in various scales, she endured, resisted, often submitted herself, often answered back and tried to stop. But she knew the limit to retain her job.

Indonesians were the ones who experienced more abuse and violence than other groups. Of the nine who reported being raped by either the male employers or by any adult sons or relatives, five were from Indonesia, two from Sri Lanka and one from the Philippines and one Thai. On the whole, 
twenty-one of them reported being directly kissed on their lips, which happened suddenly, and seven per cent experienced molestations. Like I mentioned elsewhere, most abusive acts remain invisible. The below quote gives clear indication of how abuses happen.

“...... when the lady [madam] is not at home, he [sir] always pretends that he wants to help me cleaning dishes and floor. He holds my hand and grabs the dishes. I know his intentions. Since apparently he shows his good intentions I cannot stop him. Suddenly he hugs me, hugs me tight ....I know I have no bad intention but if the lady sees it, I will be the one responsible...." B, 29, Kennedy Town, Hong Kong.

MDWs are often abused by daughters of the employers as well.

“...... the daughter at mid-night when I am sleepy and tired after the whole day work, wake me up and ask me to rub her private parts for long time. When I fall asleep she does to me too.... I was shy to ask her not to....A, 34, Aberdeen, Hong Kong"

This is obviously a sexual abuse. Most of the sufferers in fact do not know how to seek redress. Their primary intention is to 'save' their jobs. Some of them just submitted themselves at a point of time when they failed to resist the sexual advancement of the employer. Once the employer starts the practice, it never stops, it goes on until they leave the job, or the contract ends or are caught. Sexual abuse has as well influenced on psychological state because most of the reported sexual abuse and violence occurred without consent.

Threat to use violence; threat to abandon; threat to confine and deprive of food; insulting, making derogative statements about them; socially isolating them, or not allowing them have visitors are most common complaints regarding psychological and emotional torment. One respondent told me that she took a year to know that she was entitled to enjoy leave on weekend (one day) according to the contract because she did not read the contract well and she never had contact with any other compatriots in Hong Kong. In a shopping mall (while with her employers) she met a compatriot and got a contact number. She began to talk to her compatriot and knew about her entitlements. She re-read her contract. She confronted with the employer. She had to leave the job as a result. At least twenty-two per cent were not given the mandated one rest day a week, twenty-six per cent were not given statutory holidays, and more than two per cent had no day off at all.

Depression which is common among MDWs in Hong Kong comes from various sources. About 18 per cent of them reported being confined for about a year. They were just allowed to call home implying that they are kept on call 24 hours a day, 7 days a week. Insufficient sleep, exacerbated stress, 
over work and isolation strained their energy and zeal. About 43 per cent of the respondents reported being psychologically abused of any sort. Abuse of differing degrees and scales is on the increase. More and more cases are going to the court; more and more demonstrations against abuse are taking place. On 9 March 2014, hundreds of Indonesian maids marched through the streets to call for better labour rights - with some likening their working conditions to slavery.

While physical abuse or violence in general are not as high in Hong Kong as is in other Asian countries, many of the respondents reported being physically abused. About a quarter of MDWs interviewed reported being physically abused. The highest percentage of the respondents experienced pinching followed by pushing. While being victimized by husbands or adults in one home, they often did not report the abuse to female employers for fear of retribution. The following table shows that level of sexual abuse is horrifying. About 17 per cent suffered molestations; about 4 per cent reported to have been raped while another 10 per cent reported to have been attempted to be raped. Touching body and being very close to them are very common type of abuses they suffer.

Table 4. Forms of abuses suffered (Multiple response)

\begin{tabular}{ccc}
\hline Sexual abuses & $\mathbf{f}$ & \% (n=215) \\
\hline Kiss attempt & 29 & 13.49 \\
Kiss & 34 & 15.81 \\
Rape attempt & 21 & 9.77 \\
Raped & 9 & 4.2 \\
Hug attempt & 41 & 19.1 \\
Hug & 57 & 26.51 \\
Molestation & 81 & 37.67 \\
Intentional closeness on trifle issue & 37 & 17.21 \\
Touching butt and back & 26 & 12.1 \\
Intentional touch on sensitive parts & 335 & 15.34 \\
\hline & & \\
\hline Psychological abuse & $\boldsymbol{f}$ & $\mathbf{1 9}$ \\
\hline Intimidation & 41 & 10.23 \\
Insult & 22 & 6.51 \\
Ignoring & 14 & 9.30 \\
Slanderous statements & 20 & 21.86 \\
Calling by name & 47 & 12.1 \\
Showing the mistakes repeatedly & 26 & 5.11 \\
Pointing to their broke economy & 11 & 13.95 \\
Shouting at them & 30 & 6.98 \\
\hline in their own language to them & 15 &
\end{tabular}




\begin{tabular}{ccc}
\hline Physical abuse & $f$ & $\%$ \\
\hline Pulling/grabbing hair & 9 & 4.2 \\
Pushing & 23 & 10.7 \\
Beating & 5 & 2.33 \\
Kicking & 4 & 1.9 \\
Slapping & 7 & 3.26 \\
Pinching & 39 & 18.14 \\
\hline
\end{tabular}

Source: Field data

On days off, MDWs can be seen congregating throughout the city. This looks great in terms of the fact that Hong Kong employers conform to the policy of granting days off. There is no way however to overlook that many thousands are not allowed to go out. They meet their friends, buy food of their choice (Filipinos buy Jollibee, in general), gossip, and watch movies. Many of them gather together to eat home-made traditional food, sing and dance with guitars and other instruments, and take pictures. Some of them are seen to sell phone cards.

As a coping mechanism, researchers generally suggest to refuse abusive behaviour; demand reasonably predictable and rational actions and reactions; to insist on respecting your boundaries, predilections, preferences, and priorities; to demand a just and proportional treatment; to reject or ignore unjust and capricious behaviour; to never show abuser that you are afraid of him and not to succumb to blackmail (Vitanza, et al., 1995). All the sufferers cannot or do not react to abuse or violence in the identical way. This study demonstrates that around half of the total respondents were 'sort of resilient'. This does not necessarily mean that all the resilient respondents were successful in protecting them from being abused. Some fails to take up agency to resist or protest some does not. Of course, relatively new arrivals tend to be silent to the abuses. One respondent candidly said that she initially thought abuse was normal in this kind of jobs. She shared with one of her friends what was happening in the employer's house. "my friend was surprised that I was enduring all this for many months. My friend lent me some ideas (laugh...... .....wink...). I applied them. That helped me to be resilient".

Around eleven per cent reported being submitted to the abuses meaning that they accepted abusive treatment. Twenty-five per cent of them pretended that they did not mind or understand it as abuse. Around eight per cent had to terminate the contract to save themselves from abuse. This means that the level of abuse went beyond tolerance. The lowest percentage of the MDWs used resilient measures.

Sufferers hold a tendency not to disclose which delays seeking redress and remedy. Fear of further violence from the perpetrator; fear they will 
not be believed; fear others will take the side of the perpetrator; fear of being punished; desire to protect their jobs are the factors why abusive and violent cases remained underreported. The scope of sexual violence against MDWs may never be known; under-reporting is likely to be significant due to workers' isolation and the deep social stigma attached to sexual assault (Kabeer, 2001; Fry and Barker, 2001).

Many MDWs mastered, tolerated, reduced, and minimized stressful events as an effort of resilience. Two coping strategies are instrumental to solving such issues: problem solving strategies and emotion focused ones. Problemsolving strategies are efforts to do something active to alleviate stressful circumstances, whereas emotion-focused coping strategies involve efforts to regulate the emotional consequences of stressful or potentially stressful events (Folkman and Lazarus, 1980; Ullah, 2014).

Some of the resilient respondents said sufferers should inform their compatriots, friends and recruiting agents of what is happening. Perpetrators use 'non-disclosure' as a weapon. Some says it is important to react at the first attack. Though some strategies for coping with the situation may turn damaging for them. Therefore, coping mechanism should be carefully employed. About 11 per cent said they submitted themselves at abuses (sexual advancement etc.). This means that they thought there was no use to try to protect themselves. Therefore, it was for them better to submit rather than stand up to protest. About 26 per cent pretended to have not realized that the abuse was an 'abuse' and about 30 per cent tolerated the abuse because they knew the could not quit the job or could not return home. One-third of them said that they were ambivalent what to do and a few of course were forced to quit the job due to the fact that the level of abuse went beyond tolerance.

Table 5. Coping strategies (Multiple response)

\begin{tabular}{ccc}
\hline Coping strategies & $f$ & $\%$ \\
\hline Mutual/submission & 23 & 10.70 \\
Pretending & 56 & 26 \\
Tolerant/digestion of abuse & 64 & 29.77 \\
Ambivalence & 71 & 33 \\
Quitting job & 18 & 8.37 \\
Complaining & 12 & 5.85 \\
Counter threat (protective) & 8 & 3.72 \\
\hline
\end{tabular}

Source: Field data

There are debates that if human rights are upheld, rights of women or rights of children would not have been separately considered because women and children are human. This is however an ideal situation. Therefore, various 
conventions, declarations etc. dedicated to women and children rights came out. One of such conventions is the Convention on the Elimination of All Forms of Discrimination Against Women (CEDAW) which was extended to Hong Kong in 1996. Article 11 of CEDAW obligates State Parties to "take all appropriate measures" to eliminate discrimination against women in the field of employment, including protecting women's right to work and to receive fair remuneration for their work. The CEDAW Committee considers the treatment of women migrant workers to be an important issue in the implementation of the treaty (Lee and Carole, 2006).

Most MDWs in Hong Kong are initially recruited and placed with an employer by an employment agency. While MDWs from the Philippines are sometimes directly hired by employers (after the first contract is over), Indonesian MDWs are required by their government to use employment agencies. The Labour Department administers Hong Kong employment law and regulations. Both local and migrant workers are covered by local labour law, including the Employment Ordinance, Cap. 57, and the Employee's Compensation Ordinance, Cap. 282. The Hong Kong government also maintains an immigration policy known as the "two-week rule", which stipulates that MDWs will "only be allowed to remain in Hong Kong for the remainder of [their] limit of stay or for two weeks, whichever is the shorter". The twoweek rule replaced the former practice of granting a six-month renewable work visa to an MDW and allowing her to change employers in the second year of the contract if she obtained a release letter (Lee and Carole, 2006).

\section{Human rights, policies and discussions}

Any kind of abuse or violence is a violation of human rights. The picture of abuse and violence against MDWs in Hong Kong is not promising. The study shows that MDWs are more vulnerable to sexual abuse than any other forms of abuses. Isolation in the household, lack of privacy and lack of conditions to ensure personal security place the MDWs at risk of sexual abuse.

Misunderstanding, language barrier, cultural and religious differences may work as factors for physical abuses. However, what is worth mentioning is that a sizeable percentage of respondents as well mentioned that physical abuse generally comes from their madams (i.e. the wives). Some of them suggested that some madams think the MDWs' behaviour toward the husbands are often suggestive of sexual advancement. Or in any event when husbands are responsible for any such acts, the blames are hurled on the MDWs and physical abuse becomes obvious from their wives as a result.

Of the varied range of abuses, sexual abuse is the foremost one suffered by MDWs followed by psychological abuse. Their lack of agency and protection are the primary reasons for their susceptibility to abuse. Of course, gender 
issue is important in this regard. Females are more vulnerable than males to any kind of abuses.

Coping strategies varied widely among the MDWs. Many swallowed the abuses to save their jobs; a few quit their job and many others struggled with the decision to stay or quit. Only a few ( 9 per cent) expressed their satisfaction with the overall environment of their work place. As corollaries of the perpetration of the abuses, many had permanent psychological abnormalities; a few quit their job and resorted to sex work which in some cases resulted in unexpected pregnancies. Due to insufficient mechanisms for protecting the rights of the MDWs, level of abuse goes unabated.

Labor laws around the world usually exclude domestic work from its regulations or at least provide lesser protection, reflecting social biases that allow discrimination and violence in the "private" sphere to escape public regulation. Human rights violations against domestic workers remain largely invisible (Thomas, 2000; Tolman and Rosen, 2001; Human Rights Watch, 2004). In addition, migrants have little access to the judicial system due to restrictions on their movement, lack of information about their rights and, language barriers. Undocumented workers also fear that approaching government entities might lead to detention and/or deportation, as well as the likelihood of little or no action taken on their complaints.

There is no doubt that Hong Kong has a reputation for upholding human rights. It should show its commitment to human rights by adopting provisions in an international treaty that aims to protect MDWs from abuse, including allowing MDWs to live outside employers' homes. A number of incidents of gross violation of human rights of MDWs in Hong Kong besmirched the image as a reputable location for MDWs to work. One of such recent event of (April 2014) physical abuse suffered by an Indonesian domestic helper Erwiana Sulistyaningsih, whose both eyes bruised from being struck repeatedly and whose hands and feet were roasted from chemical burns. Good news is that world media has risen up against this inhuman kind of treatment. "Human rights groups have collected 103,307 signatures from more than 160 countries calling on the Hong Kong government to take immediate steps to stop the abuse of migrant domestic workers" (SCMP, 2014). It could be expected that Hong Kong meet international legal obligation to protect right of MDWs and to that end, the Hong Kong government may look into incidents of abuses and violence perpetrated on them with due diligence and prosecute violations where they occur.

The Asia-Pacific region recruits more MDWs than any country in the world, with 21.5 million working in private homes. While migrating as MDW is not a long term solution to unemployment in sending country, it is fact today. Therefore, abuses against MDWs will continue until fundamental attitudinal changes take place and policies and laws to protect MDWs are enforced. It is now time to revisit the conventional view that women's labor as domestic 
workers as a natural extension of women's traditional, unpaid role as mothers and care providers in the family. Hong Kong's legal framework is fairly stronger than that in most places with a similar size of MDWs. The fact is that Hong Kong has the political means as well to put its commitment to the protection of MDWs into practice.

\section{References}

Abella, M., 2003. Driving forces of labour migration in Asia. In: World Migration 2003, International Organization for Migration, Geneva.

Abraham, M., 2000. Speaking the Unspeakable: Marital Violence Among South Asian Immigrants in the United States. New Brunswick: Rutgers University Press.

Barry, K., 1992. Sexual Exploitation Violates Human Rights. Coalition Against Trafficking in Women, Fall (1992) [Online]. Available at: $<$ http://www.uri. edu/artsci/wms/hughes/catw/barry.htm> [Accessed 5 October 2003].

Clements, C.M., Sabourin, C.M. and Spiby, L., 2004. Dysphoria and hopelessness following battering: The role of perceived control, coping, and self-esteem. Journal of Family Violence, 19(1).

Coker, A.L., Davis, K.E., Arias, I., Desai, S., Sanderson, M., Brant, H.M. et al., 2002. Physical and mental health effects of intimate partner violence for men and women. American Journal of Preventive Medicine, 23(4).

Department of Justice Canada., 2005a. Child abuse: A fact sheet from the department of Justice Canada. Available at: <www.canada.justice.gc.ca/en/ps/fm/childafs. html $>$ [Accesed 13 October 2005].

Department of Justice Canada., 2005b. Dating violence: A fact sheet from the department of Justice Canada. Available at: <www.canada.justice.gc.ca/en/ ps/fm/datingfs.html $>$ [Accessed 13 October 2006].

Doezema, J., 1998. Forced to Choose: Beyond the Voluntary v. Forced Dichotomy. Kempadoo, K and Doezema J., eds. Global Sex Workers: Rights, Resistance, Redefinition, New York: Routledge.

Folkman, S., and Lazarus, R. S., 1980. An analysis of coping in a middle-aged community sample. Journal of Health and Social Behavior, 21.

Fry, P.S., and Barker, L., 2001. Female survivors of violence and abuse: Their regrets of action and inaction in coping. Journal of Interpersonal Violence, 16(4).

Gamburd, M., 2000. The Kitchen Spoon's Handle: Transnationalism and Sri Lanka's Migrant Housemaids. Ithaca, NY.: Cornell University Press.

Human Rights Watch, 2004. Help Wanted: Abuses against Domestic Workers in Indonesia and Malaysia. Report, 21 July. Available at: <http://hrw.org/reports/2004/indonesia 0704/>.

ILO, 2013. Domestic workers across the world: Global and regional statistics and the extent of legal protection. Geneva: ILO. 
Kempadoo, K. and Doezema, J., eds., 1998. Global Sex Workers: Rights, Resistance, Redefinition. New York: Routledge.

Lee Peggy W.Y. and Carole J. Petersen., 2006. Forced Labour and Debt Bondage in Hong Kong: A Study of Indonesian and Filipina Migrant Domestic Workers. Occasional Paper No. 16. Centre for Comparative and Public Law, Faculty of Law, The University of Hong Kong.

Lin, L. L. and Nana O., 1999. International Labor Migration of Asian Women: Distinctive Characteristics and Policy Concerns. In: Graziano B, and Anthony, P. eds., Asian Women in Migration. Quezon City: Scalabrini Migration Center.

Loper, K., 2001. Cultivating a Multicultural Society and Combating Racial Discrimination in Hong Kong. Hong Kong: Civic Exchange.

Ma E., 2007. Grassroots nationalism: changing identity in a changing context. China Review 7(2), pp. 149-167.

Machado J.M.R., 2003. Domestic work, conditions of work and employment: A legal perspective. Conditions of Work and Employment Series, (7).Geneva: ILO.

Nagy, S.R., 2013. Building a Human Security-based Framework for the Protection of Migrants in Northeast Asia, International Studies Review, 14 (2), pp.59-80.

Nagy, S.R., 2013a. Politics of Multiculturalism in East Asia: Reinterpreting Multiculturalism. Ethnicities, 14 (1), pp.1-17.

Noorashikin, A.R., Brenda, S.A. Y, and Shirlena, H., 1999. Dignity Overdue. Impacts in Singapore. International Migration Review, 33(1).

Parrenas, R. S., 2001. Servants of Globalization: Women, Migration, and Domestic Work. Stanford, California: Stanford University Press.

Price, L. S., 2005. Feminist Frameworks: Building Theory On Violence Against Women. Halifax: Fernwood Publishing.

SCMP (South China Morning Post), 2014. Worldwide petition collects 103,000 signatures to end Hong Kong helper abuse. 28 April.

Shuto, M., 2006. Labour Migration and Human Security in East and Southeast Asia. In: Kleinschmidt, H., ed. Migration, Regional Integration and Human Security: The Formation and Maintenance of Transnational Spaces. Aldershot, England; Burlington, VT: Ashgate. pp. 205-224.

Simons, L., 1999. Mail Order Brides: The Legal Framework and Possibilities for Change. In: Kelson, G. A. and DeLaet, D., eds. Gender and Immigration. Washington Square, N.Y.: New York University Press.

Smith, P.H, Thornton, G.E., DeVellis, R., Earp, J., and Coker, A.L., 2002. A populationbased study of the prevalence and distinctiveness of battering, physical assault, and sexual assault in intimate relationships. Violence against Women, 8(10).

Sobsey, D., 1994. Violence and Abuse in the Lives of People with Disabilities: The End of Silent Acceptance? Baltimore: Paul H. Brookes.

Stone, A.A., and Neale, J.M., 1984. New Measure of Daily Coping: Development and Preliminary Results. Journal of Personality and Social Psychology, 46. 
Straight, E.S., Harper, F.W.K., and Arias, I., 2003. The impact of partner psychological abuse on health behaviors and health status in college women. Journal of Interpersonal Violence, 18(9).

Thomas, E. K., 2000. Domestic violence in the African American and Asian American communities. Psychology: A Journal of Human Behavior, 37(3-4).

Tolman, R.M., and Rosen, D., 2001. Domestic violence in the lives of women receiving welfare. Violence Against Women, 7(2).

Ullah AKM A., 2014. Refugee Politics in the Middle East and the Africa: Human Rights, Safety and Identity. London: Palgrave McMillan.

Ullah AKM A., and Huque A. S., 2014a. Asian Immigrants in North America with HIV/AIDS: Stigma, Vulnerabilities and Human Rights. Springer.

Ullah AKM A., Hossain Akram M. and Islam Kazi M., 2015. Migration and migrant fatalities abroad, London: Palgrave McMillan.

Ullah AKM A., 2013. Mother's land and others' land: 'Stolen' youth of returned female migrants. Gender, Technology and Development, 17(2), pp. 159-178.

Ullah AKM A., 2013a. Bangladeshi migrant workers in Hong Kong: Adaptation strategies in an ethnically distant destination. International Migration, 51(2), pp. 165-180.

Ullah AKM A., 2010. Pre-marital pregnancies among migrant workers: A case of domestic helpers in Hong Kong. Asian Journal of Women's Studies, 16(1), pp. 62-90.

Ullah AKM A., 2010a. Rationalizing Migration Decisions: Labour Migrants in South and South-East Asia. Aldershot: Ashgate.

Vitanza, S., Vogel, L.C.M., and Marshall, L.L., 1995. Distress and symptoms of posttraumatic stress disorder in abused women. Violence and Victims, 10(1).

Wong S.L., Moore M. and Chin J.K., 2008. Hong Kong: Demographic Change, and International Labour Mobility. Demographic Change, International Labor Mobility in the Asia Pacific Region: Implications For Business And Cooperation. PECC-ABAC Conference, Seoul. Korea, 25-26 March.

World News., 2014. Hong Kong government has a duty to respect the rights of domestic helpers. 3 May.

\section{Notes}

Special administrative region of PR China

2 They are hired to assist in handling day-to-day household chores. They may be hired d locally or from foreign countries. In order to hire MDW, one needs to be a Hong Kong resident with a monthly household income of no less than HK\$15,000 or assets of comparable amount to support the employment of the helper for the entire contractual period. They should recruit the foreign domestic helper through an agency or directly 
via personal advertisement or recommendations. In either case, one has to enter into a standard employment contract as specified by the Director of Immigration and apply to the Immigration Department for an employment visa for the helper.

3 Labor laws around the world usually exclude domestic work from regulation or provide less protection for domestic workers than for other workers, reflecting discriminatory social biases that create artificial dichotomies between work associated with men in the formal public sphere, and work associated with women in the private sphere. Malaysia's Employment Act of 1955 excludes domestic workers from regulations providing maternity benefits, rest days, hours of work, and termination benefits.

\section{About Author}

\section{AKM Ahsan ULLAH}

He is Associate professor of Geography, Environment and Development studies and Deputy Dean of Graduate Studies and Research, Faculty of Arts and Social Sciences (FASS), the University of Brunei Darussalam. Dr Ullah has extensively contributed to refereed journals. He contributed chapters to a number of books, and published 17 books on migration, refugee and development studies. In his last 20 years of career, Dr Ullah taught and researched at a number of Universities in Africa, North America, Europe and Asia.

akmahsanullah@gmail.com 